SERrÀ CAMPINS, Antoni: Set estudis de literatura oral. Palma: Lleonard Muntaner Editor, 2OI2, $336 \mathrm{p}$.

\title{
Set estudis de literatura oral
}

Caterina VALRIU LLINÀS

Universitat de les Illes Balears, Palma

El professor Antoni Serrà té una llarga trajectòria com a estudiós de la literatura oral en llengua catalana. Els seus articles, comunicacions i conferències són sempre sinònim de rigor, minuciositat, claredat expositiva i aprofundiment teòric. Els seus textos són des de fa anys referència obligada entre les persones que s'interessen pel folklore, especialment en l'àmbit universitari. D'una banda, perquè omplen importants buits bibliogràfics sobre temàtiques molt concretes $i$, de l'altra, perquè per la seva qualitat i claredat són extraordinàriament útils a l'hora d'explicar i d'estudiar la literatura oral, essent una eina excel-lent per a professors i estudiants. La dispersió que sempre comporta el format article dificulta a vegades l'accés còmode a la producció científica en el camp de les humanitats i pot resultar descoratjadora en algunes ocasions. És per això que reunir en un sol volum —curosament i bellament editat - set articles extensos i de referència del professor Serrà és una molt bona iniciativa, que — a més dels aspectes pràctics ja comentats- contribueix a posar en valor i a donar rellevància a les seves recerques, i fins i tot gosaríem dir que les acosta al públic no especialista, que -lluny del circuit de les revistes científiques - no tindria ocasió de conèixer aquestes aportacions i, en canvi, sí que es pot sentir interessat en aquest llibre, atractiu ja des de la coberta mateix, que s'il-lustra amb la fotografia d'un gran i antic paraigua de llauna que és una de les icones comercials més conegudes dels carrers cèntrics de Palma. D'altra banda, la col-lecció Temps Obert en la qual es publica —i aquest volum n'és el núm. 22- és una col-lecció ja de referència en l'àmbit cultural català i en la qual trobem obres d'autors tan reconeguts en el món universitari com Vicenç Villatoro, Damià Pons, Joan Francesc Mira, Joan Mas, Carles Miralles, Joaquim Molas i molts més.

El volum s'obre amb un extens i documentat pròleg del professor Miquel Sbert i Garau, reconegut especialista en poesia oral i cant improvisat, que ens aporta les principals dades sobre l'autor i la seva obra. Com assenyala en el pròleg: «En aquest llibre, Antoni Serrà, per donar resposta (per respondre's a si mateix) a alguns dels molts interrogants que la problemàtica de la matèria té oberts, planteja, ordena i actualitza alguns dels resultats de la seva investigació, sistemàtica i persistent, fruit de molts anys de treball rigorós» (p. II). Seguidament, l'autor -en unes quantes pàgines- descriu succintament i de manera clara el lloc de la literatura oral en els estudis literaris i els principals gèneres que la conformen. Es tracta d'una síntesi tan clarivident i encertada, una breu panoràmica, que només pot ser el fruit de l'experiència docent acumulada i la reflexió sobre la matèria. Després d'aquesta introducció trobem els set articles que conformen el llibre. Foren publicats entre els anys I996 i 2008, menys un que data de I983. Per a la present edició, l'autor els ha revisats —en ocasions els ha refós- i ha inclòs alguns afegits, modificacions i esmenes que aporten coherència al conjunt. Si revisem on foren publicats inicialment cada un dels treballs, veurem que tots s'han editat 
en revistes o volums miscel-lanis de reconegut prestigi en l'àmbit de la literatura catalana: les revistes Llengua \& Literatura, Els Marges, Catalan Review i Randa, les actes dels congressos de l'Associació Internacional de Llengua i Literatura Catalanes i altres associacions de caràcter filològic o formen part de pròlegs de llibres de l'autor editats per les Publicacions de l'Abadia de Montserrat i que han obtingut algun premi.

El volum s'estructura en tres parts. La primera — sota el títol «El poeta oral i dos dels gèneres que conrea»— és dedicada a establir les característiques d'aquests singulars creadors i de les seves obres; la segona — «Fórmules de la balada i la rondalla»— inclou dos treballs sobre les fórmules, tan habituals en poesia i narrativa popular, i, finalment, la tercera part és dedicada al gènere dramàtic i, sota el títol «Teatre de composició oral i conservació memorística», aporta dos extensos i documentats articles més. Les tres parts formen un tot harmònic que revisa diversos caires dels tres principals gèneres literaris: la narrativa, la poesia i el teatre.

El primer article, «Aproximació al poeta oral de llengua catalana», que aglutina tres treballs publicats entre I999 i 2000, és una extensa i detallada revisió i estudi de tots els aspectes que conformen el perfil humà i artístic d'aquests creadors. Serrà revisa el concepte de creació oral, les diferències — quan hi són- entre el compositor i l'intèrpret, els principals glosadors que tenim documentats, el perfil humà al qual solien respondre tradicionalment i el procés d'aprenentatge d'aquest antic art. Delimita també les diferències entre els improvisadors i els reflexius i revisa la combinació que fan de tradició i creativitat en la composició de llurs obres. Val a dir que aquesta recerca i reflexió del professor Serrà vaig tenir ocasió d'escoltar-la en una conferència que pronuncià a Palma fa ja molts d'anys, posteriorment en vaig poder llegir la versió escrita en forma d'article i des d'aleshores és una referència obligada en les meves classes a la Universitat de les Illes Balears en tractar el tema dels poetes orals a l'assignatura d'Etnopoètica Catalana. El treball fa justícia a un col-lectiu de creadors que sempre han estat bandejats i oblidats dels estudis literaris clàssics, tot i la seva vàlua i interès literari, lingüístic i social.

El segon article, «Modalitats de la poesia amebea», analitza la confrontació entre els poetes orals, que pren unes formes ben determinades i s'organitza amb la seva particular i complexa litúrgia. En llegir-lo, ens assabentem que aquesta confrontació pot prendre la forma d'una topada, una demanda o un combat. Que les topades poden ser de menes molt diverses (malignes, amistoses, a distància o fictícies), que la demanda es basa en el plantejament d'un enigma, pregunta o problema que el poeta ha de resoldre de manera airosa i que el combat té tot un cerimonial establert per la tradició, amb variants geogràfiques i històriques, d'una bella complexitat que en fa un dels més interessants actes culturals basats en la paraula.

L'article sobre els glosats de tristor serví inicialment d'introducció a un llibre sobre aquest tema tan singular i poc estudiat. L'autor insereix aquesta pràctica en el seu context històric, ens explica la seva universalitat i funcionalitat, analitza les característiques del compositor i dels poemes que crea, la ritualització que en presenta l'execució, els continguts i les estructures. És un article excel·lent per la seva factura, però sobretot sorprenent pel seu contingut. L'oblit en què han caigut aquestes pràctiques poètiques, l'expressivitat i el sentiment que vehiculen fan que per al lector contemporani siguin una descoberta colpidora. Per això és 
doblement d'agrair l'elecció de l'autor en elegir treballar sobre un tema tan poc estudiat, tan desconegut en la nostra àrea cultural i que - a partir del seu estudiés divulgat i valorat com pertoca.

La segona part del llibre s'obre amb l'article «Matinet me'n llevo i altres fórmules de la baladística catalana». L'ús de fórmules és un tret bàsic en els materials literaris orals, tant en els narratius com en els poètics. Es troben profundament imbricades amb els tòpics literaris i conformen una mena de repositori o reserva formal a la qual el versador o el narrador acudeix sempre que ho necessita per a les seves composicions i molt especialment en els inicis i finals de les seves produccions. L'ús reiterat d'aquestes fórmules conforma també la competència dels receptors i permet establir una complicitat o entesa que dóna molt bon rendiment comunicatiu i és altament funcional. Serrà revisa les característiques i els usos de fórmules tan conegudes com «Quan jo n'era petitet...», "Si n'eren...», "Aquí dalt de la muntanya...», "Adéu vila de...», les tres filles dels rei, les pintetes d'or i plata, les preguntes retòriques, l'ús reiterat del tres i el set i els seus múltiples, l'estructura folkloritzada de les metamorfosis successives ( $\mathrm{Si}$ tu te fas la lluna, jo me faré...») que es presenten de forma encadenada, els diàlegs formularis, les que interpel-len o increpen els oïdors, les de cloenda que aporten informacions sobre l'autor del text o resumeixen un ensenyament moral, etc. Finalment, l'autor remarca les similituds entre les fórmules de la poesia i la narrativa oral i les connexions amb la poesia trobadoresca i aporta una extensa i ben seleccionada bibliografia de referència.

L'article següent complementa i amplia el que acabem de comentar. «Composició i estil formularis de la rondalla meravellosa» és una detallada anàlisi sobre la forma que vertebra aquest singular i extens gènere. L'autor fa especial atenció a les fórmules d'obertura i tancament - tan nombroses i variades en la nostra tradició-, a les fórmules numèriques — l'ús simbòlic del tres i el set, però també del dos-, a fórmules que al-ludeixen a personatges o a episodis que solen ser qualificats o descrits de forma tòpica i alhora simbòlica - la bellesa femenina, el bosc, el gegant devorador-, les petites fórmules rimades que remarquen el punt àlgid i recurrent de la trama, etc. També són objecte de revisió i anàlisi les fórmules d'enllaç i d'interpel-lació dels receptors i, finalment, l'estructura de la mateixa rondalla entesa com a canemàs narratiu, segons la proposta proppiana.

La tercera i última part és la dedicada al teatre de composició oral i conservació memorística i està formada per dos articles. El primer, «Formes dramàtiques de composició oral», estudia materials sovint oblidats o menystinguts pels estudis literaris canònics, això és, petites composicions teatrals sovint vinculades al cicle religiós (Nadal, San Antoni, Pasqua) o bé de caràcter còmic, obra de poetes orals i que eren dramatitzades en contextos no formals (carrers, cases particulars, tavernes). Aquests materials han tingut una sorprenent pervivència, encara que ens hagin arribat ja en forma fragmentària. És també el cas dels balls parlats de temàtica llegendària, bíblica o satírica. Serrà revisa també el teatre de diàleg improvisat, generalment monòlegs o diàlegs còmics o bé farses i entremesos. El posa en relació amb el seu equivalent italià i n'explica les característiques i funcions. Distingeix els combats de glosadors de caràcter no teatral dels que presenten una acció fingida, pròxims en aquests cas al gènere dramàtic i que constitueixen una forma teatral molt simple i arcaica. Tanca l'article un apartat de conclusions que 
remarca la presència i pervivència d'aquests materials en la cultura europea almenys des d'època medieval, tot i que no en conservem documents escrits.

Finalment, el setè i últim article es titula «Notes sobre la tradició oral i l'antic teatre popular». Reflexiona sobre la conservació memorística d'aquestes peces i estableix les característiques essencials de l'anomenat «drama sacre», entre el qual es troben peces que encara es representen avui en dia, com l'adoració dels tres reis d'Orient, el cant de la Sibil-la, els Pastorells i d'altres. També fa atenció a l'entremès còmic, molt habitual en les festes particulars com la de les matances, i els balls parlats. Eren obres que circulaven de forma anònima, sense suport escrit i per això mateix sotmeses a processos de modificacions i fragmentacions. Serrà aporta alguns textos a tall d'exemple que il-lustra de la seva descripció i posa de manifest els manlleus entre el teatre popular i la poesia tradicional.

En conjunt, podem dir que Set estudis de literatura oral és una obra madura i molt valuosa, fruit d'anys de recerca, reflexió, comparació i experiència docent i investigadora, feta amb el rigor i la solvència que l'autor ja havia demostrat en treballs anteriors. L'edició conjunta dels articles en facilita la lectura i el treball de revisió que n'ha fet l'autor els vertebra de manera adient. El volum esdevé així una peça clau de referència en el conjunt de la bibliografia catalana sobre literatura oral i obre camins i vies d'estudi i aprofundiment a altres investigadors, alhora que és de lectura plaent per als qui s'acosten a aquests temes des d'una perspectiva no especialitzada. 